\title{
Daily larval growth and RNA and DNA content of the NW Mediterranean anchovy Engraulis encrasicolus and their relations to the environment
}

\author{
Alberto García*, Dolores Cortés, Teodoro Ramírez
}

Instituto Espan̄ol de Oceanografía, Centro Oceanográfico de Málaga, Puerto Pesquero s/n, E-29640 Fuengirola, Málaga, Spain

\begin{abstract}
Anchovy Engraulis encrasicolus larvae, collected from 2 different sites in the Western Mediterrancan Sea (the Gulf of Lions and the Catalán Sea), were analyzed for daily growth rates and RNA and DNA content. An exponential function describes the growth pattern. The larvae were shown to have a growth rate of $0.56 \mathrm{~mm} \mathrm{~d}^{-1}$ at $8 \mathrm{~mm}$ (standard length). Anchovy larvae from the Gulf of Lions showed higher daily growth rates than larvae from the Catalán Sea. In accordance, sagittal size, measured in terms of otolith area and radius, of larvae from the Catalán Sea were smaller than those of larvae from the Gulf of Lions. RNA/DNA ratio ranged from 1.09 to 7.79 , and the mean RNA/DNA ratio was 4.49. Anchovy larvae from the Gulf of Lions were shown to have a higher slope in the RNA ( $\mu$ larva $^{-1}$ ) versus DNA ( $\mu$ g larva ${ }^{-1}$ ) relationship than larvae from the Catalán Sea. This indicates that the former were in better condition. However, due to the high variability of the RNA/DNA ratio, no significant differences in RNA/DNA ratio were found between the 2 areas. A preliminary study of the relationship between environmental factors and the RNA/DNA ratio was perionued for each region. The RNA/DNA ratio of larvae from the Catalán Sea correlated negatively with temperature and positively with relative fluorescence and organic matter, while in the Gulf of Lions there was a positive correlation with temperature and no relation with relative fluorescence or organic matter.
\end{abstract}

KEY WORDS: Anchovy - Larvae $\cdot$ Growth · Otolith $\cdot$ RNA $\cdot$ DNA $\cdot$ Condition

\section{INTRODUCTION}

Variability in recruitment is determined by survival during the early life stages of fish. Starvation is a primary cause of mortality during larval stages (May 1974, Leak \& Houde 1987). Poor nutritional condition can increase vulnerability to predation and hamper growth rate (Buckley 1984), increasing the time of exposure in the more vulnerable length classes (Folkvord \& Hunter 1986).

The existence of a daily rate of deposition of increments on otoliths has been extensively used for age determination and growth analysis in the early life stages of a large number of species (Geffen 1982, Campana \& Nielson 1985, Suthers et al. 1989), and more particularly in the highly variable stocks of the clu-

-E-mail: agarcia@ma.ieo.es peoid species (Methot 1983, Moksness \& Wespestad 1989, Alvarez \& Alemany 1992). Analysis of otolith microstructure may also be applied to study the influence of ambient factors on growth of individuals. Environmental conditions, mainly temperature and food availability, can produce differences in the increment widths and in the distance to the hatch check in the otolith of a species inhabiting different marine ecosystems (Campana \& Neilson 1982, 1985). Increment width differences observed in the North Sea herring have enabled the distinction of an autumn- from a spring-spawning herring (Moksness \& Fossum 1991). Different growth rates can be related to the specific productivity of different spawning grounds, as observed by Alvarez \& Alemany (1992). They compared daily growth rates of the Iberic Atlantic sardine spawning in upwelling and non-upwelling areas.

The amount of DNA, which is the carrier of genetic information, is considered constant in somatic tissues 
and is directly related to the cell numbers of an individual, and thus is a measure of size for an individual (Folkvord et al. 1996), whereas the amount of RNA in cells is directly proportional to the protein synthesis rate. Therefore, the ratio RNA/DNA is an index of the cell's metabolic rate. The nutritional condition of fish larvae can be determined from the RNA/DNA ratio (Buckley 1984, Clemmesen 1988) or by the amount of RNA in tissues (Ferguson \& Danzmann 1990, Mathers et al. 1992). Larvae subject to starvation register lower RNA/DNA ratios in comparison to fed larvae. Moreover, RNA/DNA ratios have been used to measure recent growth rate in fish larvae (Buckley 1984 Hovenkamp 1990, Hovenkamp \& Witte 1991, Westerman \& Holt 1994, Folkvord et al. 1996). A decrease in this index is accompanied by growth decrease during periods of starvation. Experimentation under controlled conditions has shown that RNA/DNA ratios are affected by ambient factors such as temperature (Buckley 1982, 1984) and prey density (Buckley 1980, Wright \& Martin 1985)

Under an EU financed project on the NW Mediterranean anchovy, a fish egg and larva survey (MAD0792) was carried out from June 27 to July 25, 1992. Within the sampled area, 2 hydrographic regions, the Gulf of Lions and the Catalán Sea, were differentiated. The Ligurian-Provenzal current brings colder waters of Atlantic origin into the Gulf of Lions in a NE-SW direction along the edge of the continental slope (Salat \& Cruzado 1981, Millot 1990), separating the less dense shelf waters from the more dense waters offshore. This current distributes the freshwater runoff of the Rhone River over the shelf, thereby producing an enrichment of its waters (Cruzado \& Velasquez 1990). In addition, there is wind-induced coastal upwelling, which further enhances its productivity. Its influence is observed on the northern coasts of the Catalonian region off the Cape Creus during spring and the onset of summer, thereby differentiating the northern region from the rest of the Catalán Sea coasts (Masó \& Duarte 1989).

This study presents the results of the analysis of NW Mediterranean anchovy daily larval growth rates and their condition. The particular environmental settings of the 2 regions covered led us to analyze the differences in daily larval growth and condition between the 2 areas. Differences in growth are based on the size-at-age relationship and the allometric differences observed between somatic and otolith growth fotolith radius and area). The differences observed in the larval condition between the 2 regions are based on the linear relationship between RNA and DNA content. Finally, as a preliminary study the influence of the 2 main environmental factors, namely feeding availability and temperature, on RNA/DNA ratios was examined.

\section{MATERIAL AND METHODS}

Sampling at sea. The fish egg and larva survey MAD0792 (Fig. 1) was carried out in the NW Mediterranean (the Gulf of Lions and the Catalán Sea), on board the RV 'García del Cid', from June 27 to July 25, 1992. coinciding with the peak anchovy spawning season. Plankton sampling was carried out with a Bongo net with a $40 \mathrm{~cm}$ mouth opening and a $200 \mu \mathrm{m}$ mesh. Another Bongo net with a $12 \mathrm{~cm}$ mouth opening and a $53 \mu \mathrm{m}$ mesh was mounted over it to sample the microzooplanktonic component. The average duration of tows was $15 \mathrm{~min}$. The sampling stations were distributed in transects perpendicular to the coast, with a distance of 10 or 12 nautical miles between them, depending on the observed anchovy egg abundances. The offshore limits of the transects were determined by the presence of anchovy eggs. At all stations, temperature, salinity and fluorescence data were measured in CTD vertical profiles. The anchovy larvae sampled were collected at the stations shown in Fig. 1. Larvae were sorted as soon as they were captured. Larvae for nucleic acid analysis were sized and frozen in liquid nitrogen. Larvae that were destined for otolith microstructure analysis were preserved in $5 \%$ formaldehyde buffered with borax at $\mathrm{pH} 8-9$.

Otolith mounting and age reading. Before otolith extraction, larvae were measured (standard length, SL) by means of a public domain image analysis soft-

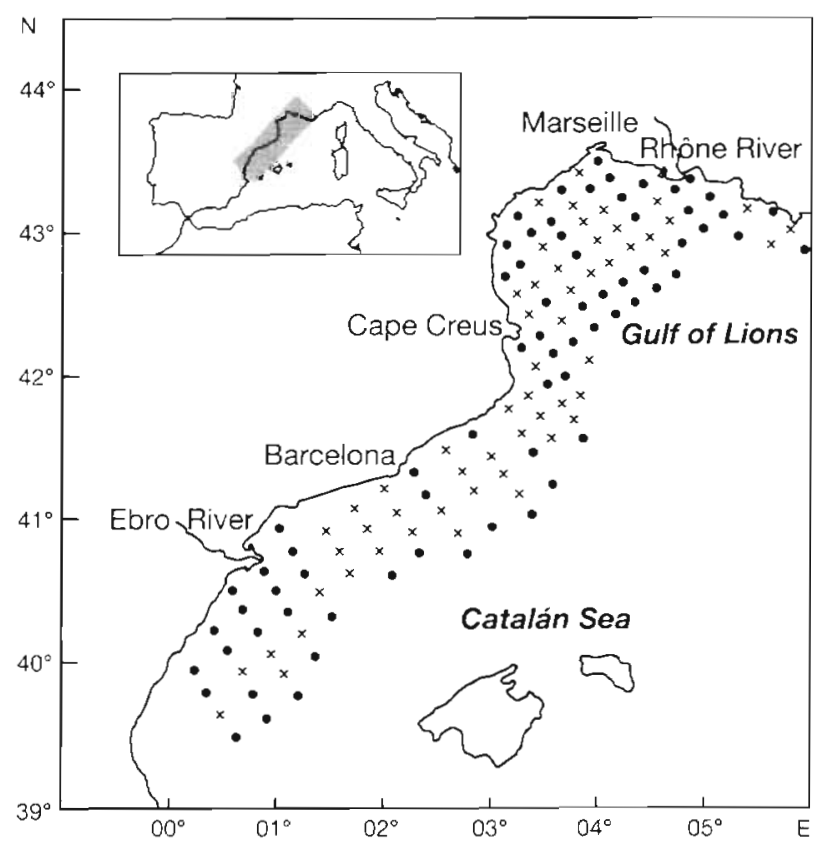

Fig. 1 MAD-0792 survey, location of sampling stations for Engraulis encrasicolus eggs and larvae in NW Mediterranean Sea. ( $\times$ ) Stations where larvae were collected for the present study 
ware system running in a Macintosh framework, developed by the U.S. National Institute of Health (NIH; Bethesda, MD). Sagittae were extracted under a binocular stereomicroscope with polarizing filters and mounted using nail lacquer as a mounting medium.

For the daily age readings, the sagittae were viewed on a video monitor and daily rings were counted using the OTO software designed by Andersen \& Moksness (1988). Area of each sagitta was measured by means of the aforementioned image analysis system. The criteria followed for the daily increment readings was based on an otolith intercalibration exercise for clupeoid larval otoliths (Anonymous 1993). The distance from the nucleus to the first distinct increment for this species was established as approximately $6 \mu \mathrm{m}$ and the increments were counted at the widest radius of the otolith.

Larval size was corrected for shrinkage due to fixation and manipulation by using Theilacker's (1980) procedure.

Extraction and quantification of nucleic acids. Nucleic acids were extracted and analyzed by utilizing the method described by Clemmesen (1988), allowing for some modifications. Anchovy larvae were homogenized at $0^{\circ} \mathrm{C}$ in Tris-buffer $(\mathrm{pH}=8)$ containing proteinase $\mathrm{K}\left(0.2 \mathrm{mg} \mathrm{m}^{-1}\right)$ using ultrasonic pulses $(2 \times 10 \mathrm{~s})$ from a Branson Sonifier 250.

The individual content of RNA and DNA was determined with a Perkin-Elmer LS-5 spectrofluorimeter, using specific dyes for nucleic acids. Ethidium bromide (excitation: $324 \mathrm{~nm}$, emission: $589 \mathrm{~nm}$ ) was used for the total quantification of nucleic acids (RNA + DNA), while bisbenzimide (H-33528) (excitation: $352 \mathrm{~nm}$, emission: $447 \mathrm{~nm}$ ) was used for DNA determination. Disposable methacrylate cuvettes were employed for the fluorescence measurements. Estimates of the DNA and RNA content of each larva were taken from calibration curves established using standard DNA (calf thymus) and RNA (yeast).

Data treatment. The larval anchovy growth models tested were based on an exponential fit and the LairdGompertz model using the Fishparm statistical package (Saila et al. 1988). The OPS software (Moksness $1990)$ was used to estimate daily growth rates $\left(\mathrm{mm} \mathrm{d}^{-1}\right)$. This program uses the files created by the OTO age reading program.

The samples used in the present study are representative of each of the 2 defined regions, the Gulf of Lions and the Catalán Sea. The border between these 2 regions is defined as Cape Creus.

In order to find out whether otolith growth and somatic growth were significantly different between the 2 regions, an ANCOVA (analysis of covariance) test was applied using log otolith radius as a covariate. Recent otolith growth was measured using the mean width of the last 5 increments. Average width of the last 5 incre- ments was plotted against the logarithm of otolith radius. The residuals of this linear regression were used as an index of recent otolith growth (Hovenkamp 1990).

ANCOVAs were also used to test the differences in $\log$ RNA by region, with log DNA and larval size as covariates. A 1-way ANOVA (analysis of variance) was carried out to test the difference in RNA content by size class in the 2 regions sampled.

Correlation analyses were performed to analyze individually the effects of temperature and food availability (as measured from relative fluorescence and microzooplankton abundance expressed in terms of organic matter) on RNA/DNA ratios by region. We consider the $20 \mathrm{~m}$ depth level, according to the observations of Palomera (1991) on NW Mediterranean anchovy larval vertical distribution, as representative in the assessment of the environmental influence of fluorescence and temperature on RNA/DNA ratios. The environmental data used for these analyses are in the EU FAR Final Report on Project MA 3.730 (García 1994). All statistical tests were carried out to a significance level of $5 \%$ (Zar 1974).

\section{RESULTS}

\section{Anchovy daily larval growth}

A total of 156 anchovy larvae were analyzed, 79 captured in the Gulf of Lions and 77 in the Catalán Sea. The size frequency distribution of the larval population analyzed varied from 4 to $22 \mathrm{~mm}$.

The daily larval anchovy growth of the whole population sampled fitted an exponential model. Nevertheless, for comparative purposes, the Laird-Gompertz growth model proposed by Zweiffel \& Lasker (1976) for the northern anchovy Engraulis mordax was tested as well. Both exponential and Laird-Gompertz models led to similar results. The estimated daily growth rates for an $8 \mathrm{~mm}$ larva were similar (0.56 and $\left.0.57 \mathrm{~mm} \mathrm{~d}^{-1}\right)$ for the 2 models. Length at intercept, $L_{0}$, of both curves fits were 4.56 and $4.57 \mathrm{~mm}$ respectively. (Table 1 ). The

Table 1. Engraulis encrasicolus. Parameters of the growth models applied: length at $t=0\left(L_{0}\right)$, specific growth rate $\left(A_{0}\right)$ and exponential decrease of growth $(\alpha)$

\begin{tabular}{|lcccc|}
\hline & $L_{0}$ & $A_{0}$ & $\alpha$ & $\mathrm{R}^{2}$ \\
\hline Exponential & 4.56 & - & - & 0.868 \\
Laird-Gompertz & 4.57 & 0.0731 & 0.0032 & 0.876 \\
Laird-Gompertz $^{\mathrm{a}}$ & 3.40 & 0.1291 & 0.0480 & 0.857 \\
Laird-Gompertz $^{\mathrm{b}}$ & 3.76 & 0.1560 & 0.0589 & - \\
Laird-Gompertz $^{\mathrm{a}, \mathrm{b}}$ & 3.40 & 0.1868 & 0.0781 & - \\
${ }^{\mathrm{a}} \mathrm{L}_{0}$ fixed at 3.4 mm & & & & \\
${ }^{ }$Data from Palomera et al. (1988) & & \\
\hline
\end{tabular}



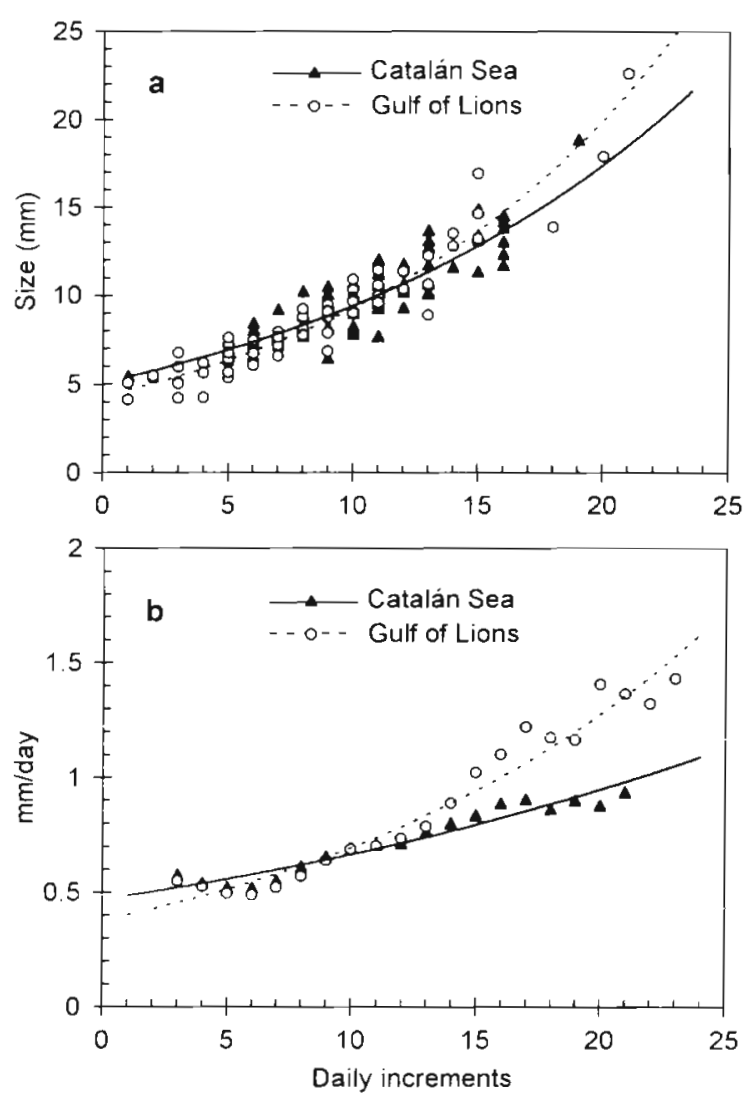

Fig. 2. Engraulis encrasicolus. (a) Size-at-age data for larvae of the Gulf of Lions, $y=4.339 \exp (0.076 x), \mathrm{R}^{2}=0.901$, and the Catalán Sea, $y=5.106 \exp (0.061 x), R^{2}=0.790$. (b) Growth rates estimated by OPS vs age for larvae of the Gulf of Lions and the Catalán Sea

Laird-Gompertz model has been previously applied to Mediterranean anchovy by Palomera et al. (1988).

When analyzing the size-at-age data by region, differences between areas were observed (Fig. 2a). These differences were also observed in daily anchovy larval growth rates (Fig. 2b). In order to test whether these differences were significant, an ANCOVA to test for the effect region on log size, with larval age as covariate, was applied. The results of this analysis showed that the interaction effect was significant, indicating differences in the daily growth rates (Table 2) of the larval anchovy populations from the 2 regions. Larvae from the Gulf of Lions showed higher growth rates.

Table 2. Engraulis encrasicolus. ANCOVAs to test for the effect of region on log SL (size) of anchovy larvae, with age as covariate. $p<0.05, \cdots p<0.0001$; ns: not significant

\begin{tabular}{|lcccr|}
\hline & df & SS & MS & F-value \\
\hline Region & 1 & $1.9 \times 10^{-3}$ & $1.9 \times 10^{-3}$ & $0.93 \mathrm{~ns}$ \\
Age & 1 & 2.19 & 2.19 & $1.077 .33^{*}$ \\
Interaction & 1 & 0.02 & 0.02 & $10.31^{*}$ \\
\hline
\end{tabular}
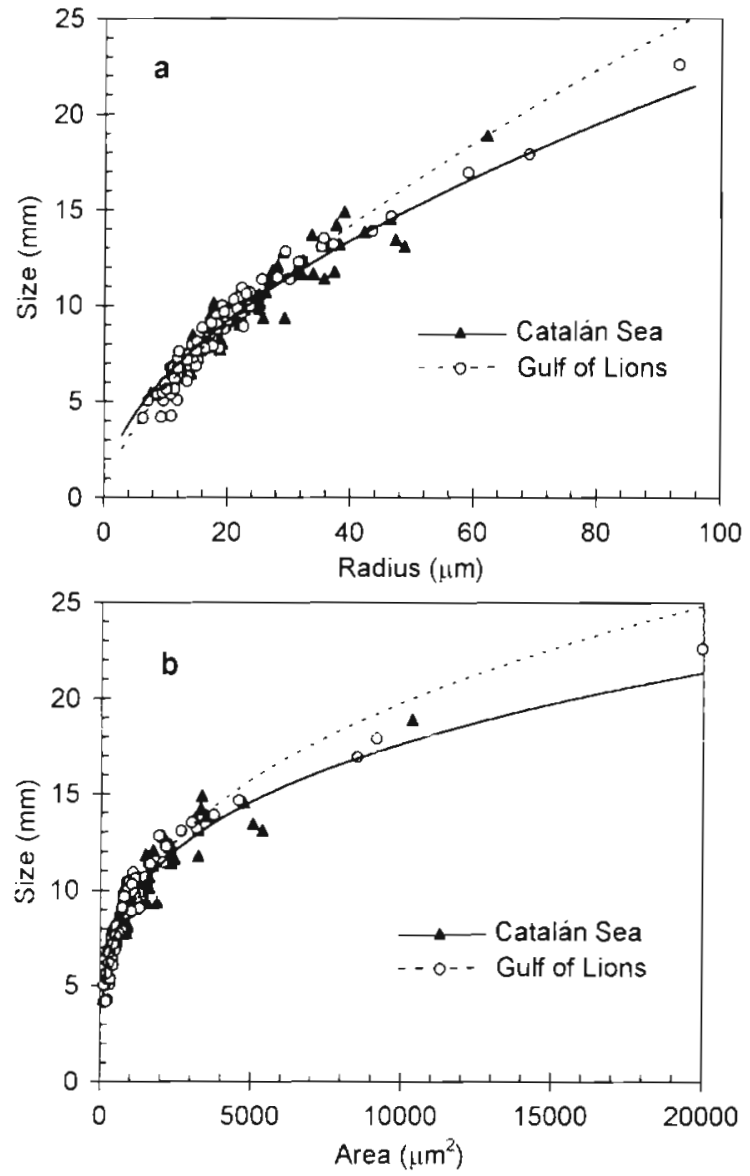

Fig. 3. Engraulis encrasicolus. Allometric relationships by region. (a) Otolith radius vs larval size: the Catalán Sea, $y=0.517 x^{1.65 t}, R^{2}=0.891$; the Gulf of Lions: $y=0.880 x^{1.415}$, $\mathrm{R}^{2}=0.924$ (b) Otolith area vs larval size: the Catalán Sea $y=0.675 x^{3270}, R^{2}=0.899$; the Gulf of Lions: $y=1.810 x^{2.822}$,

$$
\mathrm{R}^{2}=0.926
$$

The relative growth of larval length to otolith size, whether expressed as radius or otolith area, showed a potential relationship (Fig. 3). An ANCOVA to test for the effect of region on $\log \mathrm{SL}$ (size), with log otolith radius as covariate, was used. The interaction effect of region $\times \log$ otolith radius was significant (Table 3 ). Results of this analysis showed that anchovy larvae from the Gulf of Lions had smaller otoliths than those of the Catalán Sea.

Table 3. Engraulis encrasicolus. ANCOVAs to test for the effect of region on $\log$ SL (size) of anchovy larvae, with log otolith radius as covariate. $" \mathrm{p}<0.0001$; ns: not significant

\begin{tabular}{|lrrrr|}
\hline & df & \multicolumn{1}{c}{ SS } & \multicolumn{1}{c}{ MS } & F-value \\
\hline Region & 1 & 0.01 & 0.01 & $1.95 \mathrm{~ns}$ \\
Log radius & 1 & 12.23 & 12.23 & $1758.19 *$ \\
Interaction & 1 & 0.09 & 0.09 & $13.08 \%$ \\
\hline
\end{tabular}


In addition, average width of the last 5 increments were linearly related to the logarithm of otolith radius $\left(y=-4.295+4.798 x, \mathrm{p}<0.0001, \mathrm{R}^{2}=0.817\right)$. The residuals of this regression were significantly higher for larvae of the Gulf of Lions (ANOVA, $p<0.05$ ).

\section{Larval condition}

A total of 177 larvae were analyzed for RNA and DNA content, of which 83 were from the Catalán Sea and 94 from the Gulf of Lions. Larval size varied from 6 to $10 \mathrm{~mm}$.

Larvae were assigned to size classes with the aim of analyzing their individual variability in RNA and DNA content within each size class. DNA and RNA increased exponentially with larval size $\left(y=0.00118 x^{352}\right.$, $\mathrm{R}^{2}=0.992 ; y=0.00187 x^{4.03}, \mathrm{R}^{2}=0.994$, respectively) (Fig. 4a). Moreover, the 2 nucleic acids showed a strong linear relationship with each other $(y=-1.097+$ $\left.5.324 x, \mathrm{R}^{2}=0.861\right)$. The RNA/DNA ratio correlated positively with larval size $(y=2.449+0.267 x, p<$ 0.0005 ) (Fig. 4b), although due to the high variability of the index within each size class. The coefficient of the linear regression was rather low $\left(R^{2}=0.073\right)$. Individual RNA/DNA ratios varied from a minimum of 1.09 for a $6 \mathrm{~mm}$ larvae to a maximum of 7.79 for a $10 \mathrm{~mm}$ larva (Table 4). The mean RNA/DNA ratio of the whole population sampled was 4.49 ( $\mathrm{SD}=1.28)$.

To verify differences in larval condition between the 2 regions, ANCOVAs to test for the effect of region on $\log$ RNA, with $\log$ DNA and size as covariates, were applied. The interaction effects of region $x$ $\log$ DNA and region $x$ larval size were significant (Table 5). These results show that the increase of RNA is larger per unit DNA and per unit size for larvae from Gulf of Lions than those caught in the Catalán Sea (Fig. 5a, b).

The 1-way ANOVA used to test the differences of RNA content by size class showed that, except for the $8 \mathrm{~mm}$ size class, there was a significant difference in RNA content between the 2 regions (Table 6). However, the ANOVA did not show regional differences in
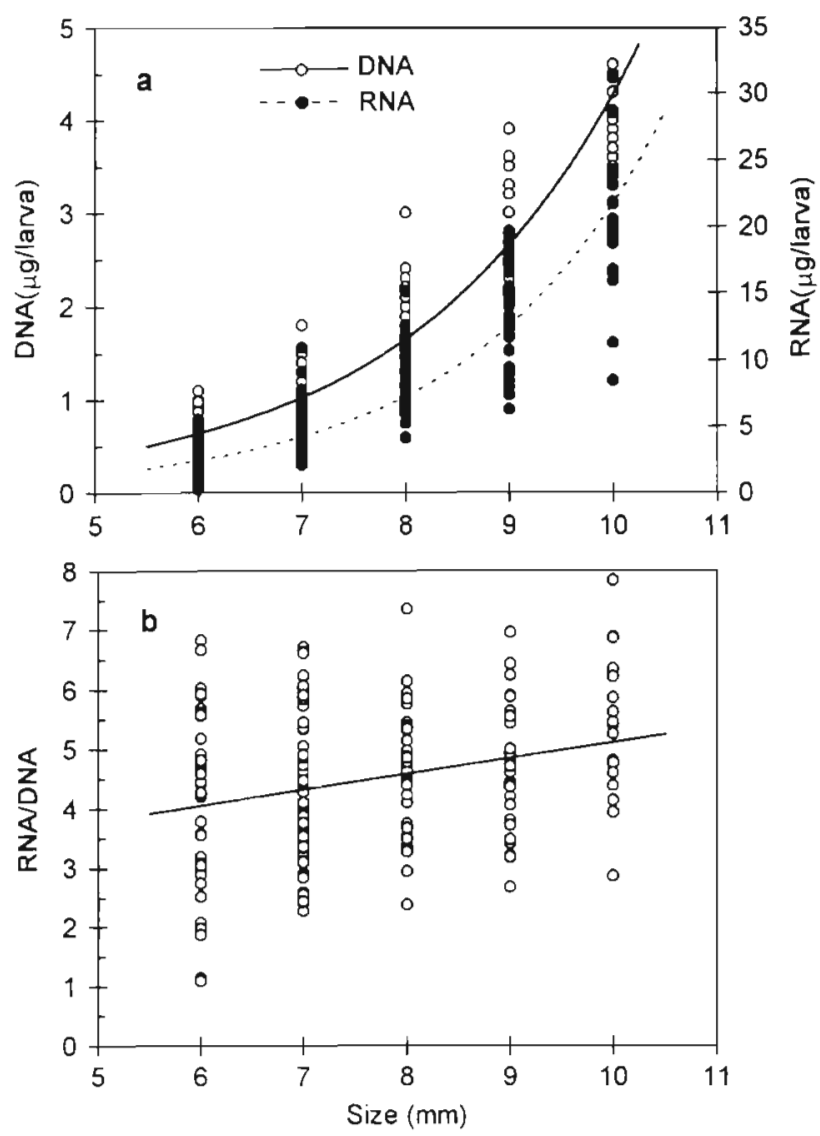

Fig. 4. Engraulis encrasicolus. Relationship between (a) nucleic acid content and larval size and (b) RNA/DNA ratio and larval size

the RNA/DNA ratio in any of the size classes $(p>0.05)$, probably due to its higher variability (Table 6).

The relationship of RNA/DNA ratio with the surrounding environmental characteristics of each region was analysed. The Catalán Sea is characterized by higher temperatures than the Gulf of Lions region $\left(18^{\circ} \mathrm{C}\right.$ and $16.5^{\circ} \mathrm{C}$ mean temperature at $20 \mathrm{~m}$ were registered in this survey, respectively). RNA/DNA ratios of the Catalán Sea anchovy larvae showed a negative correlation with temperature $(y=16.121-0.651 x, p<$ $0.05, R^{2}=0.064$ ), while larvae from the Gulf of Lions

Table 4. Engraulis encrasicolus. RNA content ( $\mu$ g larva-1), DNA content ( $\mu$ g larva $\left.{ }^{-1}\right)$ and RNA/DNA ratios by size class. Mean, standard deviation, maximum and minimum values and number of larvae analyzed ( $n$ ) are given

\begin{tabular}{|c|c|c|c|c|c|c|c|c|c|c|c|c|c|}
\hline \multirow{2}{*}{$\begin{array}{l}\text { Size } \\
(\mathrm{mm})\end{array}$} & \multirow[t]{2}{*}{$\mathrm{n}$} & \multicolumn{4}{|c|}{ RNA } & \multicolumn{4}{|c|}{ DNA } & \multicolumn{4}{|c|}{ RNA/DNA } \\
\hline & & Mean & (SD) & Max. & Min. & Mean & $(\mathrm{SD})$ & Max. & Min. & Mean & $(S D)$ & Max. & Min \\
\hline 6 & 41 & 2.47 & $(1.18)$ & 5.52 & 0.24 & 0.61 & $(0.24)$ & 1.10 & 0.21 & 4.13 & $(1.47)$ & 6.83 & 1.09 \\
\hline 7 & 52 & 4.92 & (1.75) & 10.90 & 2.09 & 1.15 & $(0.25)$ & 1.80 & 0.70 & 4.28 & $(1.27)$ & 6.63 & 2.28 \\
\hline 8 & 35 & 8.74 & $(2.54)$ & 15.10 & 4.10 & 1.92 & $(0.36)$ & 3.00 & 1.40 & 4.55 & $(1.04)$ & 7.55 & 2.41 \\
\hline 9 & 30 & 12.29 & (3.61) & 19.40 & 6.26 & 2.64 & $(0.58)$ & 3.90 & 1.80 & 4.68 & $(1.07)$ & 6.93 & 2.66 \\
\hline 10 & 19 & 20.18 & (5.31) & 31.20 & 8.47 & 3.73 & $(0.56)$ & 4.60 & 2.80 & 5.39 & $(1.20)$ & 7.79 & 2.92 \\
\hline
\end{tabular}


Table 5. Engraulis encrasicolus. ANCOVAs to test for the effect of region on log RNA of anchovy larvae, with log DNA and larval size class as covariates, $p<0.05_{i} " p<0.0001$; ns: not significant

\begin{tabular}{|lcccc|}
\hline & df & SS & MS & F-value \\
\hline Size class & & & & \\
Region & 1 & 0.03 & 0.03 & $0.98 \mathrm{~ns}$ \\
Size class & 1 & 16.81 & 16.81 & $547.22^{\cdots}$ \\
Interaction & 1 & 0.81 & 0.81 & $26.25^{\prime}$ \\
& & & & \\
Log DNA & & & & \\
Region & 1 & $1.84 \times 10^{-3}$ & $1.84 \times 10^{-3}$ & $0.01 \mathrm{~ns}$ \\
Log DNA & 1 & 19.65 & 19.65 & $1051.25^{\cdots}$ \\
Interaction & 1 & 0.08 & 0.08 & $4.12^{\circ}$ \\
\hline
\end{tabular}

show a positive correlation $\left(y=-7.937+0.743 x_{1} \mathrm{p}<\right.$ $0.005, R^{2}=0.148$ )

Individual RNA/DNA ratios of larvae from the Catalán Sea showed a positive correlation with fluorescence $\left(y=2.268+41.483 x, \mathrm{p}<0.0001, \mathrm{R}^{2}=0.235\right)$
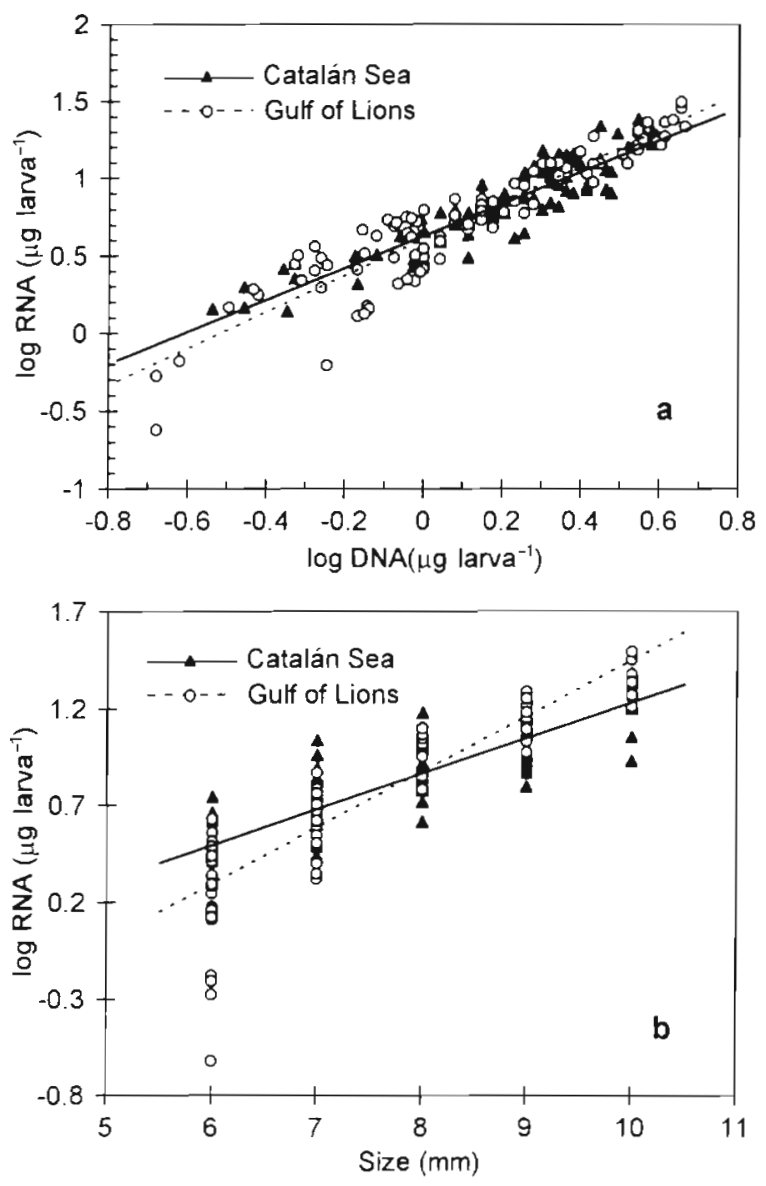

Fig. 5. Engraulis encrasicolus. Linear relationships by region of (a) $\log$ RNA vs $\log$ DNA and (b) log RNA vs larval size class
Table 6. Engraulis encrasicolus. ANOVA of log RNA and RNA/DNA by region. $p<0.05, \cdots p<0.001$; ns: not significant

\begin{tabular}{|ccccc|}
\hline Size class & df & SS & MS & F-value \\
\hline Log RNA & & & & \\
6 & 1 & 0.47 & 0.47 & $7.18^{\circ}$ \\
7 & 1 & 0.15 & 0.15 & $6.63^{\circ}$ \\
8 & 1 & 0.01 & 0.01 & $0.85 \mathrm{~ns}$ \\
9 & 1 & 0.18 & 0.18 & $14.47^{\circ}$ \\
10 & 1 & 0.08 & 0.08 & $5.50^{\circ}$ \\
RNA/DNA & & & & \\
6 & 1 & 1.99 & 1.99 & $0.92 \mathrm{~ns}$ \\
7 & 1 & $6.58 \times 10^{-5}$ & $6.58 \times 10^{-5}$ & $3.90 \times 10^{-5} \mathrm{~ns}$ \\
8 & 1 & 3.95 & 3.95 & $3.95 \mathrm{~ns}$ \\
9 & 1 & 0.12 & 0.12 & $0.10 \mathrm{~ns}$ \\
10 & 1 & 0.45 & 0.45 & $0.30 \mathrm{~ns}$ \\
\hline
\end{tabular}

and organic matter $(y=2.741+0.444 x, p<0.0001$, $\mathrm{R}^{2}=0.228$ ), while these trends were not observed with anchovy larvae from the Gulf of Lions $(p>0.5)$.

\section{DISCUSSION}

\section{Larval growth}

The growth pattern of NW Mediterraneam anchovy larvae can be described by an exponential model and also by the Laird-Gompertz growth model. Both models have proven to be adequate in describing the daily growth pattern within the range of larval sizes analyzed. The exponential growth model has been frequently used in other engraulid species, such as Engraulis mordax and Anchoa mitchilli (Kramer \& Zweiffel 1970, Cowan \& Houde 1989), while the LairdGompertz growth model proposed by Zweiffel \& Lasker (1976) for the northern anchovy $E$. mordax has been applied previously on NW Mediterranean anchovy by Palomera et al. (1988).

Both of the models showed similar estimates of daily growth rates at $8 \mathrm{~mm}\left(0.56\right.$ and $\left.0.57 \mathrm{~mm} \mathrm{~d}^{-1}\right)$ and $L_{0}$ estimates ( 4.56 and $4.57 \mathrm{~mm}$ ). These estimates differ from the $L_{0}$ value observed by Palomera et al. (1988) and Regner (1985). These authors established. an $L_{0}=$ $3.4 \mathrm{~mm}$, through biological observation of size at yolksac absorption. Different $L_{0}$ values can greatly influence the Laird-Gompertz growth parameters, specific growth rate and the exponential decrease of growth

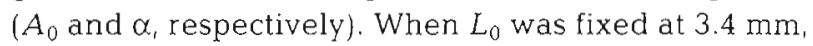
the parameters $A_{0}$ and $\alpha$ obtained were comparable to the results obtained by Palomera et al. (1988) (Table 1).

With regard to the estimations of daily growth rates, Palomera et al. (1988) reported a growth rate of $0.9 \mathrm{~mm}$ $\mathrm{d}^{-1}$ at $8 \mathrm{~mm}$ at a mean temperature of $20^{\circ} \mathrm{C}$, whereas our estimates at this size is $0.56 \mathrm{~mm} \mathrm{~d}^{-1}$ This difference can be mainly attributed to a temperature dependent 
factor, taking into account that temperature greatly influences growth rates (Buckley 1984). Our survey was carried out in June-July, during which a mean surface temperature of $18^{\circ} \mathrm{C}$ was registered, whereas larvae were collected by Palomera et al. (1988) in a warmer period (August) and a warmer area of the Catalán Sea, off the southwestern coasts facing the Ebro River mouth. In comparison, Ré (1987) reported integrated anchovy daily growth rates of this same species inhabiting estuaries of the Portuguese coasts from 0.3 to $0.4 \mathrm{~mm} \mathrm{~d}^{-1}$ at temperatures ranging from 16.5 to $19.5^{\circ} \mathrm{C}$. Methot \& Kramer (1979) calculated a growth rate of $0.37 \mathrm{~mm} \mathrm{~d}^{-1}$ for an $8 \mathrm{~mm}$ SL northern anchovy (Engraulis mordax) at a mean temperature of $15^{\circ} \mathrm{C}$. Therefore, the warmer temperatures of the Mediterranean Sea could account for the observed higher daily anchovy larvae growth rates.

The ANCOVA test applied to the growth model showed faster growth rates in larvae sampled in the Gulf of Lions region. The relatively higher growth rates of the anchovy larval population from the Gulf of Lions compared with that from the Catalán Sea may be due to the higher productivity off the Gulf of Lions. The latter region is characterized by several frontal systems, namely the shelf-slope front produced by the Ligurian-Provenzal current, the haline fronts produced by the Rhône River, which can be detected from as far off as the southern end of the Cape Creus in the form of freshwater plumes (Castellón et al. 1985), and wind-induced coastal upwelling which produces higher

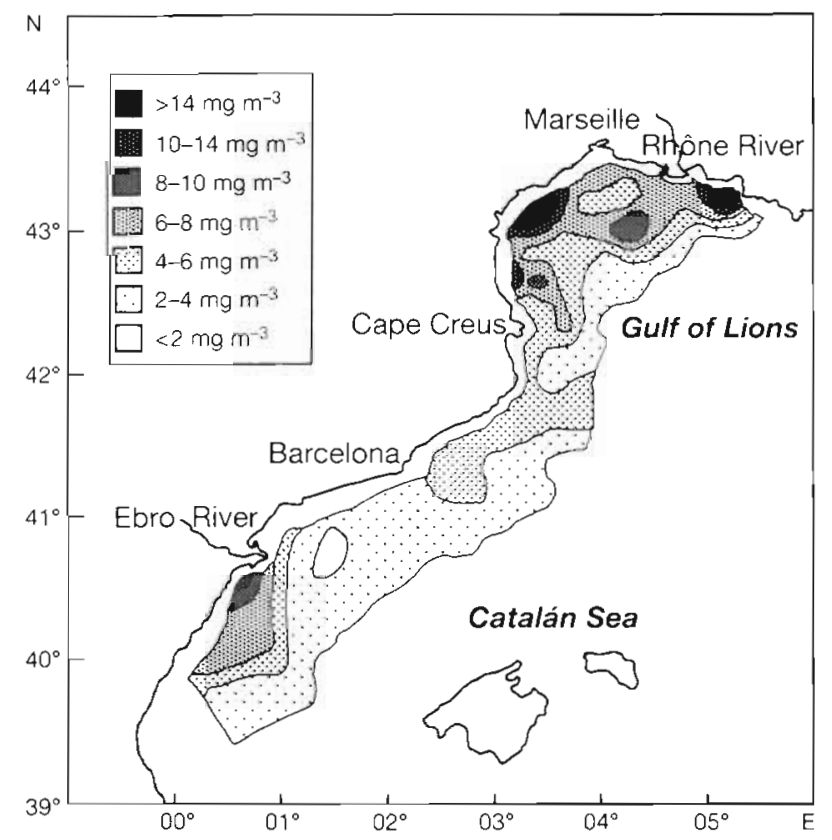

Fig. 6. Microzooplankton distribution, measured as organic matter (data acquired in FAR Project MA3.730, DG XIV), in the Gulf of Lions and the Catalán Sea nutrient and phytoplankton production (Cruzado \& Velasquez 1990). The microzooplankton (expressed as organic matter) abundance is a potential feeding resource for the anchovy larval population. Microzooplankton abundance in the Gulf of Lions was higher in general than in the Catalán Sea (Fig. 6).

On the other hand, deficient growth rates cause a longer time of exposure in the larval sizes which are more vulnerable to predation (Folkvord \& Hunter 1986); hence larvae with higher growth rates from the Gulf of Lions could have higher survival rates than larvae from the Catalán Sea. This hypothesis is consistent with the estimated anchovy larval mortality rates of Palomera \& Lleonart (1989), who observed notably lower mortality estimates in the northern Catalonian regions (in the vicinity of the Cape Creus) in comparison with the southern anchovy larval population.

The existence of uncoupling between otolith growth rates and somatic growth rates has already been reported (Secor \& Dean 1989). This happens when otolith growth occurs even when somatic growth is near zero. As a consequence, slower growing larvae have larger otoliths because they are capable of accumulating more increment counts, although producing narrower increment widths. In the present allometric analysis, the relationship between larval size and otolith radius and area showed significant differences between the 2 regions. For the same larval size classes, the Catalán Sea anchovy larvae had notably larger otoliths, accounting for slower growth rates in larvae from the Catalán Sea. In addition, analysis of the residuals showed that larvae from the Gulf of Lions had higher recent otolith growth than larvae from the Catalán Sea.

\section{Larval condition}

RNA/DNA ratios have been used as an index of recent growth rate in fish larvae (Buckley 1984). Larvae under good nutritional conditions have higher growth rates, RNA/DNA ratios and RNA content. It was interesting to test whether the conclusions obtained from the otolith microstructure analysis with the larval condition analysis were in agreement. The difference observed between the slopes of $\log$ RNA versus log DNA regressions of the 2 populations showed that the increase in RNA per unit DNA and per unit length was higher for larvae from the Gulf of Lions. A higher rate of increase in RNA per unit DNA indicates a higher metabolic rate, hence higher rates of protein synthesis. Therefore, larvae from the Gulf of Lions were in better condition than larvae from the Catalán Sea. This could be due to the effect of different environments on larval condition. These results are in line with the growth differences observed from size-at-age data. 
The mean RNA/DNA ratio of the whole anchovy population sampled was 4.49. As a comparison, Clemmesen (1989) found a mean RNA/DNA index of 3 for field-captured Atlantic herring. There is no experimental data on RNA/DNA estimates for anchovy Engraulis encrasicolus with which a critical RNA/DNA value could be established. Clemmesen (1994) established a critical value of 1.2 for $10 \mathrm{~mm}$ herring larvae starved for 6 to $9 \mathrm{~d}$. From the present analysis, $74.6 \%$ of the anchovy larvae had RNA/DNA ratios between 3 to $6,12.4 \%$ had values over 6 , and only $1.1 \%$ had values under 1.2 . RNA/DNA ratios in field-captured larvae are generally higher than those observed in reared larvae (Buckley 1984, Robinson \& Ware 1988, Clemmesen 1989). It is normal to expect few larvae with an RNA/DNA ration under 1.2 in the field, since these are more liable to die.

In spite of the fact that RNA/DNA ratios show high variability within each size class, they showed a positive relationship with size. Clemmesen (1994) also observed an increase of RNA/DNA ratios in well-fed Baltic herring larvae. Larger larvae have greater nutritional reserves in their tissues (Håkanson 1989), which could explain the increase of the index with size, making them more resistent to prolonged periods of starvation without substantially affecting their RNA/DNA index (Clemmesen 1989). This increase in RNA/DNA ratio can also be due to cellular size enhancement (hypertrophy) (Goss 1966) or to an allometric increase of tissues with different RNA/DNA ratios (Bulow 1987).

It has been shown that the RNA/DNA ratio is related to water temperature (Buckley 1984). The analysis of individual estimates of RNA/DNA indices of both larval populations indicated a positive correlation with the prevailing temperature for larvae from the Gulf of Lions system $(p<0.005)$, whereas it correlated negatively with temperature for larvae from the Catalán Sea waters $(p<0.05)$. Buckley (1982) found that temperature was the dominant growth factor when larvae have adequate food supplies. However, when the temperature range is narrow, inversely, food availability becomes the predominant factor for growth and condition (Buckley 1979, 1984).

The relation between food availability and RNA/DNA ratio was analyzed. Results of these analyses showed that RNA/DNA in the Catalán Sea was highly correlated with microzooplankton organic matter and relative fluorescence $(p<0.0001)$. Food availability could represent a limiting factor for larval condition off the Catalán Sea coasts. In contrast, food availability does not show a relationship with RNA/DNA in larvae from the Gulf of Lions, and therefore it does not seem to be a determinant factor for larval condition in larvae from the Gulf of Lions, as the correlation analysis ( $p>0.5)$ indicates. These results show regional differences, as observed in Iarval growth.

\section{Conclusions}

The growth pattern of NW Mediterranean anchovy larvae is well defined by a power function. Larval otolith microstructure was successfully used to differentiate the growth rates of 2 population in different environments. This difference was also shown by the relationship between somatic growth and otolith growth. For the same larval size classes, the Catalán Sea anchovy larvae had larger otolith sizes. The rate of increase in RNA per unit DNA was higher in larvae from the Gulf of Lions, therefore indicating better condition. The difference observed in larval growth rates and condition between the 2 regions implies an environmental cause. Based on this hypothesis, it will be necessary to take into account environmental factors in future studies on larval growth and condition in the field.

Acknowledgements. The authors are indebted to the Department of Analytical Chemistry and Blochemistry of the University of Málaga. We also thank Angel Carpena who helped with much of the otolith lab work and Jose Maria Ortiz de Urbina for his statistical advice. Also, thanks to Dr Isabel Palomera for providing the data on microzooplankton and to Dr Arild Folkvord and Dr Erlend Moksness for their valuable comments on the manuscript. Finally, we thank the financial aid of the EU for supporting the FAR MA-3.730 project on the NW Mediterranean anchovy.

\section{LITERATURE CITED}

Alvarez F, Alemany F (1992) Regional growth differences in sardine (Sardina pilchardus Walb.) larvae from Cantabrian and Galician coasts. ICES CM H:9

Andersen T, Moksness E (1988) Manual for reading daily increments by the use of a computer programme. Flødevigen Meldinger 4. Directorate of Fisheries, Flodevigen Biological Station, Arendal

Anonymous (1993) Report of the Clupeoids Otolith Microstructure Workshop. Inf Téc Inst Esp Oceanogr 145

Buckley LJ (1979) Relationships between RNA-DNA ratio, prey density and growth rate in Atlantic cod (Gadus morhua) larvae. J Fish Res Bd Can 36:1497-1502

Buckley LJ (1980) Changes in ribonucleic acid, deoxyribonucleic acid and protein content during ontogenesis in winter flounder, Pseudopleuronectes americanus, and effect of starvation. Fish Bull US 77:703-708

Buckley LJ (1982) Effects of temperature on growth and biochemical composition of larval winter flounder ( $P_{\text {seudo- }}$ pleuronectes americanus). Mar Ecol Prog Ser 8:181-186

Buckley LJ (1984) RNA-DNA ratio: an index of larval fish growth in the sea. Mar Biol 80:291-298

Bulow FJ (1987) RNA-DNA ratios indicators of growth in fish: a review. In: Summerfelt RC, Hall GE (eds) The age and growth of fish. The Iowa State University Press, Ames, p 45-64

Campana SE, Neilson JD (1982) Daily growth increments in otoliths of starry flounder (Platichthys stellatus) and the influence of some environmental variable in therr production. Can. J Fish Aquat Sci 39:937-942

Campana SE, Neilson JD (1985) Microstructure of fish otolith. Can J Fish Aquat Sci 42:101.4-1032 
Castellón A, Salat. J, Masó M (1985) Some observations on Rhône river fresh water plume in the Catalán coast. Rapp Comm Int Mer Médit 29(3):119-120

Clemmesen CM (1988) A RNA and DNA fluorescence technique to evaluate the nutritional condition of individual marine fish larvae. Meeresforschung 32:134-143

Clemmesen CM (1989) RNA/DNA ratios of laboratory reared and wild herring larvae determined with a highly sensitive fluorescence method. J Fish Biol 35:331-333

Clemmesen $C$ (1994) The effect of food availability, age or size on the RNA/DNA ratio of individually measured herring larvae: laboratory calibration. Mar Biol 118:377-382

Cowan JH, Houde EH (1989) Growth, growth variability and survival of Bay anchovy (Anchoa mitchilli) larvae in mesocosm enclosures. ICES CM L:3

Cruzado A, Velasquez Z (1990) Nutrients and phytoplankton in the Gulf of Lions, Northwestern Mediterranean. Cont Shelf Res 10(9-11):931-942

Ferguson MM, Danzmann RG (1990) RNA/DNA ratios in white muscle as estimates of growth in rainbow trout held at different temperatures. Can J Zool 68:1494-1498

Folkvord A, Hunter JR (1986) Size specific vulnerability of northern anchovy (Engraulis mordax) larvae to predation by fishes. Fish Bull US 84:859-869

Folkvord A, Ystanes L, Johannessen A, Moksness E (1996) RNA:DNA ratios and growth of herring (Clupea harengus) larvae reared in mesocosms. Mar Biol 126:591-602

García A (1994) Northwestern Mediterranean anchovy: distribution, biology, fisheries and biomass estimation by different methods. Final Report, FAR Project MA3.730, DG-XIV, Directorate General for Fisheries of the Commission of The European Communities

Geffen AJ (1982) Otolith ring deposition in relation to growth rate in herring (Clupea harengus) and turbot (Scophthalmus maximus) iarvae. Mar Biol 71:317-326

Goss RJ (1966) Hypertrophy versus hyperplasia. Sciences (NY) 153:1615-1620

Hakånson JL (1989) Analysis of lipid components for determining the condition of anchovy larvae, Engraulis mordax. Mar Biol 102:143-151

Hovenkamp F (1990) Growth differences in larval plaice Pleuronectes platessa in the Southern Bight of the North Sea as indicated by otolith increments and RNA/DNA ratios. Mar Ecol Prog Ser 58:205-215

Hovenkamp F, Witte JIJ (1991) Growth, otolith growth and RNA/DNA ratios of larval place Pleuronectes platessa in the North Sea 1987 to 1989. Mar Ecol Prog Ser 70:105-116

Kramer D, Zweiffel JR (1970) Growth of anchovy larvae (Engraulis mordax Girard) in the laboratory as influenced by temperature. CalCOFI Rep 14:84-87

Leak JC, Houde ED (1987) Cohort growth and survival of bay anchovy Anchoa michilli larvae in Biscayne Bay, Florida Mar Ecol Prog Ser 37:109-122

Masó M. Duarte CM (1989) The spatial and temporal structure of hydrographic and phytoplankton biomass heterogeneity along the Catalán coast (NW Mediterranean). J Mar Res 47:813-827

Mathers EM, Houlihan DF, Cunningham MJ (1992) Nucleic acid concentrations and enzyme activities as correlates of growth rate of the saithe Pollachius virens: growth-rate estimates of open sea fish. Mar Biol 112:363-369

May RC (1974) Larval mortality in marine fishes and critical period concept. In: Blaxter JHS (ed) The early life history of fish. Springer Verlag, Berlin, p 3-19

Methot RD Jr (1983) Seasonal variation in survival of larval northern anchovy, Engraulis mordax, estimated from aged distribution of juveniles. Fish Bull US 81:741-750

Methot RD Jr, Kramer D (1979) Growth of northern anchovy Engraulis mordax, larvae in the sea. Fish Bull US 77 : 413-423

Millot C (1990) The Gulf of Lions' hydrodynamics. Cont Shelf Res 10:885-894

Moksness E (1990) Manual for OPS (Otolith Population Statistics). Flodevigen Meldinger 5. Directorate of Fisheries, Flodevigen Biological Station, Arendal

Moksness E, Fossum P (1991) Distinguishung spring- and autumn spawned herring larvae (Clupea harengus L.) by otolith microstructure. ICES J Mar Sci 48:61-66

Moksness E, Wespestad V (1989) Ageing and back-calculated growth rates of Pacific herring, Clupea pallasi, larvae by reading daily otolith increments. Fish Bull US 87:509-530

Palomera I (1991) Vertical distribution of eggs and larvae of Engraulis encrasicolus in stratified waters of the Western Mediterranean. Mar Biol 111:37-44

Palomera I, Lleonart J (1989) Field mortality estimates of anchovy larvae, Engraulis encrasicolus, in the western Mediterranean. J Fish Biol 35(Suppl A):133-138

Palomera I, Morales-Nin B, Lleonart J (1988) Larval growth of anchovy, Engraulis encrasicolus, in the Western Mediterranean. Mar Biol 99:283-291

Ré P (1987) Ecology of the planktonic phase of the anchovy Engraulis encrasicolus (Linnaeus, 1758) within the Mira estuary. Invest Pesq 51:581-598

Regner S (1985) Ecology of planktonic stages of the anchovy, Engraulis encrasicolus (Linnaeus, 1758), in the central Adriatic. Acta Adriat 26:1-113

Robinson SMC, Ware DM (1988) Ontogenetic development of growth rates in larval pacific herring, Clupea harengus pallasi, measured with RNA/DNA ratios in the strait of Georgia, British Columbia. Can J Fish Aquat Sci 45: 1422-1429

Saila SB, Recksierk CW, Praeger MH (1988) Basic Fishery Science Programs. A compendium of microcomputer programs and manual of operation. Elsevier Science Publishing Co, New York

Salat J, Cruzado A (1981) Masses d'eau dans la Mer. Méditerranée Occidentale: Mer Cataláne et eaux adjacentes. Rapp Comm Int Mer Médit 27:201-209

Secor DH, Dean JM (1989) Somatic growth effects on the otolith-fish size relationship in young pond-reared stripet bass, Morone saxatilis. (Walbaum). Can J Fish Aquat Sci 46:113-121

Suthers IM, Frank KT, Campana SE (1989) Spatial comparison of recent growth in postlarval Atlantic cod (Gadus morhua) off southwestern Nova Scotia: inferior growth in a presumed nursery area. Can J Fish Aquat Sci 46(Suppl 1): $113-124$

Theilacker $\mathrm{G}$ (1980) Changes in body measurements of larval northern anchovy, Engraulis mordax, and other fishes due to handling and preservation. Fish Bull US 78:685-692

Westerman M, Holt GJ (1994) RNA:DNA ratio during the critical period and early larval growth of the red drum Sciaenops ocellatus. Mar Biol 121:1-9

Wright DA, Martin FD (1985) The effect of starvation on RNA:DNA ratios and growth of larval striped bass, Morone saxatilis. J Fish Biol 27:479-485

Zar JH (1974) Biostatistical analysis. Prentice-Hall, Englewood Cliffs, NJ

Zweiffel JR, Lasker R (1976) Prehatch and posthatch growth of fishes. A general model. Fish Bull US 74:609-621 